\title{
Towards the end of bequest? The life cycle hypothesis sold to seniors
}

\section{Critical reflections on the reverse mortgage financial fashion}

\author{
Rumo ao fim da herança? A hipótese do ciclo de vida \\ vendida aos idosos
}

Reflexões críticas sobre a tendência da hipoteca reversa

Anne Gotman*

\begin{abstract}
Resumo: A hipoteca reversa, destinada a proprietários idosos conhecidos como "house rich, cash poor", lhes dá a oportunidade de dispor do valor de suas casas sem ter que devolvê-lo durante a vida, a não ser que a moradia seja vendida ou desocupada pelo proprietário. Este tipo de empréstimo bancário visa reduzir despesas públicas com cuidados de longo prazo e manter o bem-estar das pessoas idosas e seus padrões de consumo. Inspirado pela hipótese do ciclo de vida, significa "comer a casa" para satisfazer suas necessidades, abandonando assim a idéia de transmissão. Este artigo discute a lenta decolagem do mercado das hipotecas reversas, a hipótese do ciclo de vida que fundamenta esses empréstimos e as políticas públicas que lhes regem, e também as conseqüências financeiras e materiais da compra para os proprietários idosos. Embora os relatórios de avaliação e estudos de caso destaquem as pressões que levam idosos ainda jovens a se engajarem numa "solução de último caso", se quer saber se os titulares destas hipotecas realmente são, como os economistas gostariam, uma vanguarda em conformidade com as previsões da hipótese do ciclo de vida.
\end{abstract}

Palavras-chave: hipoteca reversa; hipótese do ciclo de vida; herança; idosos; políticas para idosos

\begin{abstract}
Reverse mortgages are designed for senior homeowners said to be "house rich, cash poor." They allow for the extraction of equity from homes without payments being made until death or the house is sold. They are designed to alleviate public longterm care expenses, as well as to maintain senior citizens' well-being and consumption standards. Inspired by the life cycle hypothesis, they imply "eating the house" in order to meet one's needs, as well as giving up the idea of bequest. This paper addresses the lengthy take-off of reverse mortgage markets, the life cycle theory sustaining reverse
\end{abstract}

* Sociologue, Chercheure du CNRS - CERLIS-Université Paris Descartes, Paris, France. $<$ anne.gotman@parisdescartes.fr>

\begin{tabular}{|c|c|c|c|c|c|}
\hline Civitas & Porto Alegre & v. 11 & n. 1 & p. 93-114 & jan.-abr. 2011 \\
\hline
\end{tabular}


mortgage policies, and the financial and material consequences of their purchase for aged homeowners. Whereas evaluation reports and case studies bring to light constraints already driving indebted younger elders to come to what appears to be a 'last resort solution', one may ask whether reverse mortgage buyers do represent a kind of avantgarde conforming to the life cycle hypothesis requisites.

Keywords: reverse mortgage; life cycle hypothesis; bequest; seniors; old age policies

\section{Introduction}

Reverse mortgages are a very specific form of spending housing wealth which allows homeowners to borrow money by transferring ownership of the house to the bank. In Europe, they are used on a very limited scale, mainly in the United Kingdom, Ireland, Germany, The Netherlands, Finland and France. They are also beginning to be used in the United States and Canada, as well as in Australia, New Zealand, Singapore, and Japan. Currently, taking out a mortgage for purposes other than buying a house is not a widespread phenomenon, "although it is growing in importance" (Housing Finance in the Euro Area, 2009). What is a reverse mortgage, how does it work and to what ends? Reverse mortgages rest on converting equity into cash. Their principle is simple: a homeowner mortgages a limited part of her house's value, takes out benefits either in the form of monthly or term payments, or a line of credit, but instead of having to make monthly repayments to pay off the principle and the interests, she is authorized to pay off the whole debt at one time, when she dies or if she sells her house. Because lenders don't want to wait too long to be paid back, reverse mortgages are exclusively offered to people of a certain age - from 60 to 62 or 65 years, depending on the country. Indeed, reverse mortgages are especially designed for ageing homeowners said to be "house rich, cash poor," and who may want extra cash to meet their needs for their old days.

In order to introduce the materiality of reverse mortgages for households, I shall refer to the storytelling used by operators in charge of the market. Here is the story of Angus and Lise published online by the Canadian Home Income Plan (CHIP) (www.chip.ca) to explain the opportunity to buy a reverse mortgage for a retired family whose cash is poor compared with their house value.

Angus M. and Louise M. had enjoyed full and busy lives raising seven children in a small farming community outside of Ottawa. Many of their offspring, now grown up and on their own, still lived 
close by and visited frequently. It would have saddened everyone if their parents had been forced to sell the family home. But that appeared to be the only option. They had limited income and were carrying an $\$ 85,000$ mortgage along with $\$ 3,000$ in credit card debt. They had approached the bank for a second mortgage but were turned down because they didn't qualify. Then their financial advisor told them about a CHIP Home Income Plan. "It's a wonderful product," enthused Angus. "Our debts are now all paid off and we're at ease. Without those monthly payments, we have the extra cash we need to do things and our income can now cover any surprise costs that we encounter. The best part is that I don't have any stress.

Compared with forward mortgages, the peculiarity of reverse mortgages is striking: instead of being a "falling debt - rising equity" loan, it is on the contrary a "rising debt - falling equity" one. Reverse mortgage loans rest mainly upon two conditions: the borrower's age and their house's value; unlike classical mortgages, income is not taken into consideration. It means for instance that a 62-year-old American HECM (Housing Equity Conversion Mortgage) borrower is allowed to borrow up to $63 \%$ of the value of his house, while an 80 -year-old can borrow up to $78 \%$ of it. The maximum equity that can be borrowed by a homeowner of such or such an age is determined by the risk of negative equity ${ }^{1}$. In addition to this relative maximum limit to be borrowed is also a fixed limit which for HECM loans amounted to 180000 dollars in 2006.

Reverse mortgages were launched in the eighties, and began to spread more significantly in the nineties. It is on the grounds of an already present increased longevity and the future growth of public expenses for elders' care that reverse mortgages were considered as a solution to tackle the overwhelming cost of an ageing population. As they allow for the extraction of cash from walled equity (or "sleeping equity," as French politicians say), the so-called "reverse mortgage loans" permit older homeowners to meet their expenses while staying at home. "No place like home": the title of an American survey on reverse mortgages (Rodda et al., 2000), clearly shows what is at stake in their promotion. Instead of going into nursing homes, elderly homeowners can have proper care by "using [their] home to stay at home" (Stucki, 2005) - they will be able to afford it due to their loan's proceeds. Thus, the cost of older age

1 Negative equity happens when the final debt is higher than the value of the mortgaged property. If it is not insured, buyers (or their heirs) have to repay the total amount of their debt; on the contrary, when negative equity is insured, as it is now in almost every country, the buyer (or her heirs) cannot owe more to the bank than the mortgaged property value. 
should decrease for society as well as for individuals. This last assumption, linked directly with the so-called "life cycle hypothesis" from which reverse mortgages were inspired, will receive special attention here for its erasure of the possibility of heirs' inheriting anything but the repayment of the house.

As an object for sociology, the reverse mortgage issue is only starting to be explored. While economists began earlier to discuss the inputs and outputs of loans for banks, insurance companies and buyers, much sociological work has been driven by authorities in charge of experimental selling programs. These post-evaluation studies aim to bring together the supply and demand and therefore focus, first, on how adequate the plans are in terms of information, counselling, and variety of offers; and, second, with whom and to what ends they comply - or fail to do so. Supply strategies can also be documented through the work of academic advocates - the so to say "experts" - engaged in the promotion of reverse mortgages to professionals, keen to bring to the fore their potential pros and cons. Academic research on the subject is mainly to be found in general literature about housing wealth equity and its uses, of which reverse mortgages represent only a very small part. Only a few studies deal with the relation between reverse mortgages and inheritance issues, a subject we documented in France by the case study we directed through interviews and focus groups comprised of notaries whose attendance at the loan's signature is mandated by law (Assier-Andrieu \& Gotman, 2009). This paper will first turn to expectations in regard to reverse mortgages endorsed by public authorities and markets, including the life cycle hypothesis upon which these loans rely. The uses and users of reverse mortgages will then be examined as well as buyers' constraints and motives in order to understand the rationales at work and to see how buyers actually deal with the issue of bequest. Before that, some information about the spread of reverse mortgages in the United States and some other countries will also be addressed.

\section{The spread of reverse mortgages in the US and elsewhere}

The first reverse mortgage loan to be offered in the United States by a private bank goes back to 1961. But its actual beginnings can be dated to the period between 1980 and 1989, when the federal HECM program was introduced. The HECM programme was given a major impulse by the National Council on Aging (NCOA), which duly contributed to the promotion of the idea of the reverse mortgage as a means of financing long-term care for seniors wishing to age at home, while the American Association of Retired Persons (AARP) expressed sharp watchfulness to protect consumers vulnerable to 
such an altogether new and complex financial instrument. By 1989, after almost ten years of experiments and surveys, the Department of Housing and Urban Development (HUD) selected fifty lenders and launched the HECM Demonstration programme which was to become permanent eleven years later, in 1998. Today, HECM loans represent 90 per cent of the total number of reverse mortgages in the United States. The last estimation published in 2007 cited 345,762 HECM originated loans. This number, lower than estimates launched in the $1990 \mathrm{~s}$, which projected 800,000 potential customers, is also much lower than a 2005 estimate which anticipated up to 13.2 million potential buyers (Redfoot et al., 2007). The same year, a more targeted survey estimated the potential HECM loan buyers population to reach 8.8 million (Merlis, 2005). Today, compared to the 30.8 million people aged 62 and over, the actual number of HECM loan detainees represents hardly one per cent. Indeed, a recent public evaluation of the Housing Equity Conversion Mortgages programme (HECM) suggested less optimism than previous forecasters had thought; it suggested that reverse mortgages may serve more as a "niche product" than a "mainstream solution" (Redfoot et al., 2007). Reverse mortgages actually came in line with "alternative mortgages" and "creative financing" instruments, which did allow lenders to make loans with terms that obscured their total cost. Sold on secondary markets, they were also to fill the financial "bubble" and, as everyone is now aware, they put an end to Alan Greenspan's dream of an everlasting real estate price increase.

Meanwhile, the launching of reverse mortgages was slow in the United States as well as in other countries. Indeed, the markets were equally ignored by buyers and lenders alike whose associations repeatedly appealed to government support in order to propel the item forward. In Canada, where the Canadian Home Income Plan was created in 1986 in Vancouver, the gap between the advertised benefits of elderly homeownership as a "hidden wealth" and the targeted population whose budgets are unable to meet everyday life needs or unexpected expenses is significant. The Canadian Mortgage and Housing Corporation (CMHC) shows a highly cautious attitude towards reverse mortgages, and the market, still considered in its infancy (Report on Reverse Mortgages, 2006), covers only 2.5 per cent of the 68,000 house-rich and cashpoor homeowners free of mortgages and considered as potential candidates. As the last report to the Parliament published on this subject in 2003 puts it: "Reverse mortgage has never gained wide acceptance in Canada" (Le Goff, 2003). In Great Britain, "Equity release loans" represented only 0.5 per cent of the mortgage market by 2006, i.e. around 26,000 annually-generated loans, 
of an average value of 40,000 pounds per household (Terry \& Gibson, 2006). Here too, the costs appear to be a deterrent. For a lifetime mortgage whose annual interest rate is $7 \%$, compounded every three months for instance, the debt doubles in the first ten years and doubles again in the following ten years. Moreover, the Equity Release schemes remain undermined by the devastating consequences of the lack of insurance against negative equity in the case of the first loans launched on the market.

In New Zealand, a nation of homeowners, where $85 \%$ of elderly people are considered to have an appropriate income, the lasting tradition of house ownership and bequest accounts for the narrowness of the market. In Australia as well, reverse mortgages represent hardly $0.3 \%$ of home equity owned by homeowners aged 60 and over. Nevertheless, this still immature market could significantly expand, since the home equity value/average income ratio is twice as high as in the United States, for instance. Moreover, recent reports on the future intergenerational debt point out the appropriateness of such a solution regarding public health expenses for an ageing population (What Are the Health Challenges Facing Australia?, 2005). As for Japan, South Korea, Hong Kong and Singapore, reverse mortgage markets cannot be openly taken into consideration by governments because of the unclear roles of the State and the family towards old persons' care. Nevertheless, unlocking equity plastered into the walls could be promoted to boost consumption and economic growth as a whole, as Japanese households leave an estate equal to twenty-five years of consumption, and real estate equal to twenty years of consumption (Mitchell and Piggott, 2003) - compared to 5 per cent in the United States, for instance.

Should such a lengthy take-off be ascribed to people's old-fashioned habits?, experts ask. To "overcome deeply held beliefs regarding the use of home equity among today's old homeowners", one should address educational guidance to the elderly, suggests Stucki (2005, p. 49). "Deeply held beliefs" to combat include: housing wealth not regarded as a fungible asset; a desire to leave a bequest; and, saving home equity as insurance for emergencies. Those beliefs, supposedly rooted in a fear of impoverishment embodied in the Great Depression experience, and ascribed to what is called the "depression era mentality", are regarded as a generational phenomenon. In the United States as well as in other countries, obstacles to the extension of the reverse mortgage market are similarly ascribed to the current older generation's way of life and its anchored frugality. Consequently, educational efforts are pointed towards younger generations, among whom consumption credit is assumed to be already taken for granted, and who are ready for a "paper wealth" economy. 


\section{Towards the redistribution of responsibilities between government and private citizens}

"With an estimated \$2.1 trillion tied up in home equity, this financial asset has the potential to dramatically increase the ability of seniors to pay long-term care at home", says an American reverse mortgage expert (Stucki, 2004, p.2). As United States governors regularly point to the financial crisis of the Medicaid system for which states are responsible, and as the federallyfunded Medicare system is repeatedly said to be doomed to bankruptcy by Republican administrations, reverse mortgages appeared to many experts as a "bright spot." Indeed, more than $80 \%$ of Americans aged 65 and over own their house. As the general trend for retirement and public health policies is getting less and less generous while a growing number of pensioners can be declared "house rich, cash poor", it may reasonably be stated that the house should be used as a cash-tank to be tapped into for everyday life and old age needs. Indeed, the link between reverse mortgages and welfare scale back can be seen from their side-effects for American senior citizens whose federal social benefits may be reduced because of their loans' proceeds.

In Australia, the youngest of the OCDE countries nevertheless enjoying a high proportion of aged homeowners ( $82 \%$ of persons aged 65 and over), the first Home Equity Conversion loan to be launched in 1987 was subsidized by the Department of Social Security (Ong, 2008). But here, the highly politicallyrisky pension issue prevented governments from putting reverse mortgages on the agenda and officially supporting reverse mortgage markets as they did in the United States. In the United Kingdom, where 70\% of people aged 65 and over are homeowners, reverse mortgages are only one financial instrument amongst others - including the Mortgage Equity Withdrawal (MEWs) designed to "bank on housing" (Smith, 2005) and boost consumption. The link between Equity Release schemes and old age care policies is apparent through means testing to which much social aid is subjected and which may lead reverse mortgages buyers to loose their benefits (Terry and Gibson, 2006). In France, where the so-called "prêt viager hypothécaire" (life-mortgage loan) was introduced in 2006 by executive order alongside revolving credits, reverse mortgages are bound to contribute to the general improvement of consumer credit instruments still at a relatively low level in comparison with other European countries. Here too, homeownership is high owing to the importance of the "second" home: $73 \%$ of French households with at least one retired member own their primary home, and 76\% own at least one home. The process is sold publicly according to a "modernisation of the economy" policy. 
Nevertheless, national pro-family associations were quick to warn their fans against what they considered a potential threat for pension rights, and showed up with a sharp opposition to the principle of guaranteeing consumer credit on home property. Lenders were slow to participate, whereas notaries kept a "wait and see" position. Still, most were already convinced of their legitimacy, being assumed that public expenses could no longer continue to increase unless a state bankruptcy risk was accepted (Assier-Andrieu and Gotman, 2009). Time has come for citizens to be more 'responsible', they say. Just as responsibility was previously called upon to draw people into home ownership, it is now put forward to encourage them to tap into their equity.

Politics on that matter may not be evenly explicit from one country to the other. But, despite rhetorical differences, reverse mortgages are to be understood in the new social division of work asking of governments to take charge of economic growth and of individuals to meet their own needs. Whereas they sustained strong homeownership policies, governments now duly agree with individual responsibility, "moral selves" and personal empowerment mottos in order to promote a new way of sharing social costs. Where home equity represents the largest component of household assets and where pensions as well as health policies are scaled back in line with international treaties and agreements, housing wealth should sustain citizenship in a new way. In accordance with international forums appealing for new institutional arrangements (Howe and Healy, 2005), it is expected that responsibilities should be redistributed between governments, voluntary associations and private citizens. More specifically, pensions and long-term care for the ageing population, considered a "risk," should be fuelled both by intra- and intergenerational transfers. Eventually, reverse mortgages activate intergenerational transfers in two ways, for they are to be used not only by seniors for their own sake at the expense of children's inheritance, but also to help needy adult heirs-not-to-be.

\section{The theoretical ground for reverse mortgages: the life cycle hypothesis}

"According to the 'life cycle hypothesis' of savings and consumption, says the 2007 HECM evaluation report in its introduction, one would predict that individuals would pay down debts and build savings in their working years, then diverse those savings to support consumption in their old years" (Redfoot et al., 2007, p. v). The life cycle hypothesis quoted by the HECM evaluation report is a theoretical model of consumption which aims to draw middle class attitudes' towards consumption patterns in relation to their income 
curve. Early attempts to establish a link between the consumption plans of an individual, her income and income expectations from childhood, through the work participation years, into retirement and eventual death - i.e. during the life cycle -, appeared during the Roosevelt New Deal era, when consumption was put at the forefront of Keynesian economic concerns. Nevertheless, the life cycle hypothesis' full paternity is granted to the Nobel prize winner Modigliani who, along with Brumberg, sharply defined the "hypothesis" on both theoretical and empirical grounds. The key statement of the life cycle hypothesis was the specification that the life-time utility function be homothetic - this permitted planned consumption for each period to be written as a function of expected wealth as seen as the planning date, the functional parameters being in no way dependant on wealth but upon age and tastes. Sharpening their hypothesis further on, the authors specified than an individual would plan to consume the same amount in real discounted terms each year. Regarding the hypothesis, the assets accumulation curve has a humpback shape whose maximum takes place just before retirement, and decreases from then until death. Throughout that process, desire for bequest and initial assets were set to zero. However, the authors did show that bequests could be accounted for within the homothetic utility function itself if that became necessary. That accumulation does not equal zero at death is due to the impossibility to predict the exact time of one's death. This model assumes that consumption is the only so to say "egoistic" individuals' horizon; that it is exclusively shaped by age and taste; and that accumulation simply meets the desire to transfer purchasing power in time.

One can easily see how reverse mortgages comply with the life cycle hypothesis, while at the same time it clears the path for self-welfare. Retired people are deemed and indeed invited to "tap into their equity" and to "unlock the savings stored in the house" in order to support themselves in their old age. If properly foreseen, the reverse mortgage should lead to home equity being consumed. Nevertheless, as reverse mortgage markets do not come up so far to actuaries' great expectations, their supporters are intrigued by the patterns of asset decumulation in retirement: "One intriguing finding, says one, is that seniors typically do not draw down their housing equity wealth to support general non-housing consumption needs" (Stucki, 2004, p.8). Instead, home ownership continues to be high in old age, while home equity does not appear to fall with age either, as Venti and Wise (2001) confirmed after having taken a second look at their own results. From 1989 to 1999, home equity among American seniors had risen by almost $7 \%$ over the last decades whereas the amount of debt they carried on the home declined by $10 \%$. 
In other words, the resilience of retired persons to unlock their savings from their house is already an interpretation in terms of consumers' attitudes. People's ability to assess the risks of age is already assessing that old age is a risk, and has to be thought primarily in that way. On the contrary, it seems that lay people think of their old age in terms of a safety net and security, and that home equity is their best insurance. Only hasty shocks, like a spouse's death or a spouse entering a nursing home, can lead elderly people to liquidate their equity, say Venti and Wise. Elderly retired persons do continue to keep their savings; they even increase their asset levels when selling a house. Thus, Venti and Wise maintain that elderly retired persons' financial choices are inconsistent with "a substantial interest for these products [reverse mortgages]" (Venti and Wise, 2001, p.4). This may be the reason why, more than because of technicalities, a lack of demand could explain the reluctance towards reverse mortgages as well as their failure. Therefore, the next question is: what can be inferred about demand, from empirical surveys on reverse mortgage buyers? What pushed them to dissave in later life? Do they represent the enlightened minority ready to eat their house at the expense of bequeathing it to their offspring? And do they represent the future end of the bequest motive erased by the life cycle hypothesis?

\section{Reverse mortgages' performances for households}

What do reverse mortgages actually bring to their buyers? May reverse mortgages buyers be regarded as the elderly avant-garde? And if so, in what way? From evaluation reports and academic research carried out on the subject, results appear contradictory at first glance, except for one thing: the high cost of reverse mortgage loans. First, reverse mortgage costs are very high because buyers are accountable for the principle and for the accrued value of the interests - making the estimation of interests in the long run a rather complicated matter for lay persons who are the bulk of reverse mortgage clients. The mandatory counselling sessions designed by the HECM programme to help clients' decisions do not mention the total cost of the debt, for example, one year, five years or ten years after the purchase (Scholen and Belling, 2006). This lack of revelation is one reason why we have called it the "silent debt" (Assier-Andrieu and Gotman, 2009). Second, interest may be fixed interests but more and more often they are adjustable interest rates, making the amount of debt all the more difficult to appreciate again for lay persons. Third, the upfront costs are also high for they encompass origination fees and a mandatory mortgage insurance premium. Finally, loan's cost depend on the payment option selected by the borrower (tenure payments, term payments, 
credit lines - the more commonly used - and combinations of both). In addition to these costs, the borrower must properly maintain his house in order to keep its marketable value at the initial level. Annual inspections ensure that. The high level of reverse mortgage costs is considered everywhere as the first reason for their unpopularity. Reverse mortgages are indeed one of the most expensive loans whereas, as must be recalled, they are designed for less welloff homeowners. They may go up to $30 \%$ of interest. Furthermore, reverse mortgages are all the more expensive as they serve small payments ${ }^{2}$. This may highlight why some people tend to say: "After a short while, you realize you are in deeper than you thought you'd be" (Rodda et al., 2000, p. 89). But, apart from financial consequences, there are residential consequences too. This story, issued by a Canadian survey (Report on Reverse Mortgages, 2006), tells how the reverse mortgage can jeopardise the very old years spent in a home it was supposed to secure.

Mr. A and Mrs. A are a married couple. Both of them are 68 years old; both retired at age 65. Mr. A's and Mrs. A's pensions provide them with a modest income. Their savings are minimal. Mr. A and Mrs. A own a house that was built in the 1920s and is located in a working-class neighbourhood. Apart from the house and a 10-yearold car, Mr. A and Mrs. A own no major assets. The house has risen considerably in value since Mr. A and Mrs. A purchased it. It is currently valued at $\$ 300000$. In fact, the house is in need of repair. Its condition is becoming a source of anxiety for Mr. A and Mrs. A.

Mr. A and Mrs. A have always dreamed about travelling across North America in a recreational vehicle. They hoped to spend their early retirement fulfilling this dream. But their current income will not permit them to do it. They decide to borrow the money they need to fulfil their goals. They find the choices to be baffling, as neither has much experience in evaluating financial products. They become attracted to a product called a "reverse mortgage," because it is a product that is only available to senior citizens, it is a loan geared to the value of their house rather than their level of income, and it does not require them to make periodic payments. They complete the application procedure for the reverse mortgage, which includes an appraisal of their house. Mr. A and Mrs. A are told that they are eligible to borrow $\$ 80000$, with interest at an annual rate of 7.25 percent, compounded semi-annually. They agree to borrow that amount.

2 Had a 74-year-old HECM buyer, for instance, borrowed, by 2006, only half of the maximum amount allowed (which was up to 180000 dollars at that time) and taken a lump sum without borrowing anything after, he would owe 150000 dollars twelve years after that. During the same period, if the value of his house increased by 4 per cent a year, the cost of the loan would equal $31 \%$ of its value. At the same time, he would have half of his house left. (Redfoot et al., 2007). 
Mr. A and Mrs. A use $\$ 25000$ from the proceeds of the reverse mortgage to purchase a used recreational vehicle. They also use $\$ 5000$ to begin making repairs to their house. They invest the remaining $\$ 50000$ in an annuity, which gives them approximately $\$ 325$ per month in income. The payments from this annuity supplement their pension income and enable them to travel.

Ten years after they enter into the reverse mortgage, Mr. A and Mrs. A, now 78, decide that they wish to move. They have found it difficult to keep their home in proper repair and wish to move to a smaller, more manageable property. They are informed that the reverse mortgage will come due when they complete the sale of their house. They are also informed that they owe slightly more than $\$ 160$ 000 , or double the amount that they borrowed. This surprises $\mathrm{Mr}$. A and Mrs. A. Their home has not appreciated greatly in value. $\mathrm{Mr}$. $A$ and Mrs. A are not sure that the amount they will receive from its sale will enable them to purchase the property they want, after the reverse mortgage has been paid off.

Whereas reverse mortgage costs are unanimously attested, and long-term dangers cautiously mentioned by evaluators, satisfactory indexes may at first appear contradictory. Here, the formulation of the questions is at stake, but the moment of inquiry is critical as well: was it at the beginning of the loan, after a few years, or later? From the first representative survey on HECM clients launched in 2007, for instance, it appears that a vast majority of buyers were satisfied with their choice: $58 \%$ declared themselves to be completely satisfied, 25\% answered mostly satisfied and 12\% partly satisfied (Redfoot et al., 2007). Yet, the authors cautiously pointed out that $92 \%$ of the sample had been interviewed at most three years after their purchase. Therefore, these figures only reflected "their short-term assessments." Over time, as they review the substantial growth in their reverse mortgage debt, current borrowers "may become more keenly aware of how much of their equity has been consumed by loan fees and interest" (ibid., p. 104).

A previous HECM evaluation had shown that motives for such a choice were mainly three: buyers wished to stay at home, to have an "extra cushion", and to stay independent while keeping the quality of life they were used to. "It made the difference between living and just existing", some said. Others were happy to be free of continuous worries and enjoyed "feeling pretty comfortable" (Rodda et al., 2000). That's also what Leviton's research brought to the fore in interviews with Massachusetts reverse mortgage programme clients, although with a less enthusiastic tone. Here, interviewed widowers between their seventies and nineties, for whom identity was said to be "bound 
up in the house", acknowledged that the loan was their only way to avoid moving from their familiar neighbourhood and being cut from their family ties, while being able to stay at home "free and clear" (Leviton, 2001). The very low income households for whom the programme was designed were adamant to have "a clear head for the rest of their life" and to keep control on a frugal way of life that could be jeopardized by any unexpected expense - for them a car repair could be a "real blow." Therefore, the first benefit of the reverse mortgage was "to keep up with their bills" in the same way as before, i.e. without credit. On the other hand, inquiries conveyed in the United Kingdom (Davey, 1997) and in New Zealand (Davey and Wilton, 2006) show a high degree of satisfaction amongst more well-off buyers who mainly enjoyed having liquidities and being independent from youngsters they were even able to visit overseas. The only reason for feeling insecure mentioned by respondents was not so much their own financial situation as the lenders' reliability in the long run.

Under satisfaction indicators, the actual uses of reverse mortgages offer a somehow different picture of reasons buyers are buying and seeking profits. If asked about the reasons why they made this choice, the HECM survey respondents declare, in decreasing order: "emergencies", "the unexpected", "everyday expenses", "improved quality of life", "home repairs/ improvements", "pay off mortgage debts", "property taxes/insurance", "pay off non-mortgage debts", and only then "health or disability" (Redfoot et al., 2007). Asked now about the first reason why they bought a reverse mortgage, the same respondents quote, first: "pay off mortgage debt." When finally asked what was the first use of the reverse mortgage proceeds, the first item quoted was "pay off non mortgage debt" (27\% of respondents), then "home repairs/improvement", and "improved quality of life" (18\% each), "everyday expenses" (17\%), "emergencies/the unexpected" (10\%), "health or disability" (9\%), and "property taxes/insurance" (5\%) (ibid.) In other words, improvement of quality of life comes first only for $18 \%$ of the respondents, whereas all other uses which may be summed up as a means to stay at home come to $82 \%$. As the authors conclude, "reverse mortgage borrowers are not using their loans as a basic income supplement, at least not in a straightforward way." Contrary to previous predictions, buyers "clearly use their loan proceeds primarily to retire debts and pay for upfront expenses " (Redfoot et al., 2007). As confessed by some respondents, reverse mortgage was indeed a "last resort option." French notaries, faced with the same kind of demands, appeared somewhat worried: "There are people who want to make a prêt viager hypothécaire to buy out their other loans. I recorded a lot of consumption loans and, as far 
as I'm concerned, this is never a good sign. It makes me worried. Not that I think they are impecunious. But they are a little bit enthusiastic about it." "It may be a very good instrument", warns another, "but unless they win on the lottery, I do not see how they will be able to pay back, unless they sell the house of course. But with such an interest rate, the selling price will never pay the debt. One should be realistic. Heirs won't be able to pay back the debt, and as a consequence the house will be the banker's property. It can't end otherwise" (Assier-Andrieu \& Gotman, 2009, p.198). Years earlier, Venti and Wise (1991) had already come to the same conclusion. They found that median income older homeowners would only extract from reverse mortgages a reduced increase of their income.

In the United Kingdom as well as in New Zealand, where home repairs or improvement comes first, conditions for reverse mortgage buyers do not seem so precarious. Still, paying off debt comes at the second rank of actual uses of equity release loans, including bills and mortgage debt in New Zealand, whereas in the United Kingdom, the second item to be quoted was health and care. Besides, while people were keen to stay independent from their offspring - a repeated statement abundantly used by reverse mortgage advocates -, they could sometimes buy a reverse mortgage to help an heir-not-to-be whose business was faltering, to save their home and pay for their forward mortgage. Helping offspring too is a praised benefit duly advertised by reverse mortgage lenders.

In the US, another two indicators suggest that reverse mortgages are mainly used to meet difficulties rather than to improve quality of life, or to "live life to the full" as an Australian website for seniors puts it: first is the decline of the tenure payment option (chosen by $47 \%$ of buyers by 1991 but only $19 \%$ by 2005); second is the increasingly younger age of buyers (Redfoot et al. 2007). The same survey emphasises the growing number of people coming up to retirement with a substantial debt, and, amongst people still free of debt at this stage, their increasing debt rate. Similarly, the Australian Senate Report highlights that older people appear to be taking greater debt into retirement than was previously the case (A Decent Quality of Life, 2008). Going further, a Canadian report on reverse mortgages links up their development to the increasing level of debt among aged people (Report on Reverse Mortgages, 2006).

Whereas reverse mortgages may pay off a forward mortgage (this payment is currently mandatory for HECM loan buyers), ownership may become a lifelong mortgaged property. Moreover, when people buy a reverse mortgage to get "free" of debt, they get in fact another highly expensive 
debt, but a silent one, which won't have to be paid back, or else by the heirs. Therefore, if reverse mortgage buyers may be qualified as an avant-garde population, it is because they experience a reversing trend of the post World War II old age financial wealth and security where savings embodied in house ownership could encompass old age security needs and a wish to bequest all together, instead of being converted into credit for consumption. In this way, they would be the first to behave according to the life cycle hypothesis. To French notaries, the link between reverse mortgages and consumption policies was clear: reverse mortgages are good for consumption policies, whether they are so for people or not. "On paper, it looks okay. One can help people, but in fact the legislator's profound idea is to allow people to consume more by mortgaging their property", says one. "The prêt viager hypothécaire is made to consume better or to face a blow but still, it is a result of consumption", says another. Such an orientation was of real concern to some: "Somewhere I consider it has something of the nature of impoverishment. I am not sure it goes in the right direction, but it goes in the direction of favouring consumption." Another notary goes further: "Do borrow to get more resources and consume more. Get poorer! On the macro-economic level, it is easy to understand, an amassed stock won't make the economy go around. Only consumption can do it" (Assier-Andrieu and Gotman, 2009, p.199-200).

\section{How reverse mortgage buyers deal with their wish to bequest}

In Australia, where death duties have been abolished and bequest is sanctified, polls have shown that the inheritance issue could be a major obstacle to reverse mortgage development (Dolan et al. 2005). Similarly, in Canada, the Law Reform Commission of Saskatchewan (Reverse Mortgages, 2006) displays its concern about the "most obvious drawback of the reverse mortgage" which "depletes the homeowner's equity" and reduces "the value of the estate that can be left to heirs." Yet, as already mentioned, reverse mortgage supporters do favour lifetime downward transfers and inter vivos gifts. They argue for the borrowers' ability to help their children with loan proceeds, acknowledging the growing need of intergenerational support across the family. But whereas this invitation to draw house equity down to help children is a special token for poorer families, low income homeowners are the very same who tend to be the most reluctant towards reverse mortgages. The British asset-rich, income-poor pensioners interviewed by Maxwell and Sodha (2006, p. 55-56) felt that "they had spent their working lives saving their home." Therefore, "it was not a resource they were prepared to tap into their old age." Said one: "I feel fidgety about the whole thing, it's taken years and 
years of hard graft to get where I am and no one can take that away." Among the factors shaping similar negative attitudes, say Maxwell and Sodha, "the desire to leave a bequest is critical. The implications of equity release for the inheritance they were able to leave to their children and grandchildren made it extremely unattractive." "It's robbing the heirs", says one. "The home is all we have to pass on", says another. "Children come first", he adds. "If you had no family ties, it'd be great", others say. Here, as in France, the United States, and elsewhere, regardless of whether their histories and reasons differ, ownership has deep symbolic importance. Planning its lifetime consumption would "be going backwards", one interviewee said. Similarly, Gibler and Rabianski (2006), studying American elderly interest in reverse mortgage, maintain that the two main hindrances to reverse mortgage acceptance are willingness to keep ownership free from mortgage and willingness to bequeath. Both HECM evaluations had come to highlight the conflict between the bequeathing faculty, regarded as a "responsibility" even among people without children, and the reverse mortgage principle. They outlined the bequest issue as being "crucial." Leviton (2001) too concluded from her inquiry that the wish to bequeath as it is currently observed leaves the reverse mortgage market with a limited span, that of a niche product.

Children's approval of parents' decision to buy a reverse mortgage is usually considered as a major proof of the fall of the inheritance rationale. In most cases, borrowers' children had been informed of their parents' plan and most often they did agree with it, when not pushing them to go into it. A New Zealand survey holds that $90 \%$ of borrowers' children approved their parents' decision to buy an equity release loan. In this respect, children's approval of parents' reverse mortgage purchases fits perfectly with the current rule of generational autonomy. They want to see their parents out of trouble, even at the expense of a future inheritance, especially if they happen to be better off themselves. Yet, this percentage came down to 63 amongst respondents who finally decided not to buy such loans (Davey \& Wilton, 1997). Indeed, behind what appears at first glance like consensus and the children's willingness to give up their future inheritance, interviewed parents voiced a slightly different mood. Some felt that it was similar to a "handhout or something you should be ashamed of" and were embarrassed to tell their children (Rodda et al., 2000). The New Zealand survey voices a wider sort of embarrassment directed towards the social milieu. Borrowers confessed their reluctance to speak about something said not to be "socially approved." They also confessed that such a solution betrays management and financial failure (Davey \& Wilton, 2006). Behind the older generation's autonomy lies the idea of mismanagement, 
for new dependency to these markets' financial products is taking over from a dependency to renting markets that homeownership was supposed to overcome.

French notaries' opinions about the future of transmission and reverse mortgages are those of financial managers the profession longs more and more to aspire to. Yet, some confess their doubts in regard to the end of bequest. Therefore they don't foresee how reverse mortgages could be a success. "French people are keen to be able to transmit stock to their children; this is the reason why the prêt viager hypothécaire does not work today. I am not sure it will be a success, because the prêt viager hypothécaire leads to leaving nothing to the children. One shall leave a stock eaten by debt", says one. Some stress the human need of bequeathing: "Inheritance had good sides. It brings heirs together at least for a moment. It is the last remaining thing. One wants to extend one's personality through what is left to others. I think the human being is necessarily attached to it." Yet, like reverse mortgage supporters, other notaries ascribe the will to bequeath to historic generational attitudes. Prewar generations are keen to pass on their stock, but will their grand-children behave in the same way? "Pre-war generations want to transmit, whatever it is, a flat or a country house. People are keen to find their roots again, so they want to transmit. Maybe our children will be tied to it in the same way, but what about our grand-children and our great-grand-children? They may change completely..." Changes may occur, says another, and a new philosophy may replace the old one: "People have got this idea of transmission. Maybe this is going to change, maybe we shall get to this new philosophy, I am not absolutely convinced of that, but who knows?" Other notaries wish for these changes to come, and do appeal in their favour. Some of them welcome the prêts viagers hypothécaires as an Anglo-Saxon technique that should push French society to evolve and get "colder" attitudes towards property. As this notary clearly states, property should be eaten: "I think this is excellent. I think society has not developed enough. This is somehow an Anglo-Saxon technicality. Regarding patrimony, this technicality is rather cold minded, and a property manager cannot have feelings towards property. He should take it as a token or as a thing. Figure a daily ordinary need no one can fulfil, there is money aside, so you mobilise it in advance, provided with certainty that the house will eventually be sold in order to pay. So far comes the response to immediate needs. So I am totally convinced, my conviction is that this institution must supersede current mores and customs. I stand for a patrimony to be eaten, not squandered." For others, financial trends are at stake. They suggest behaving according to them: "Real estate becomes more and more financial, says another. 
Like people, it has now several lives. Wouldn't it be better to sell one's house progressively before dying than leaving it closed, ruined, then sold?" Yet, the same notaries admit the dark face of reverse mortgages: "Sure, they will postpone the burden of debt and impoverish forthcoming generations" (AssierAndrieu and Gotman, 2009, p.201-203).

Are "Anglo-Saxon" mores and customs different from continental ones, as suggested by the above comment? Are some countries enjoying stronger social policies and other welfare states more adverse to banking on housing as well as to tapping into house equity? Is housing wealth not to be considered anymore for inheritance? British social research on inheritance in the United Kingdom has identified a "shift (albeit uneven) away from the idea that housing wealth is primarily a legacy for future generations towards the notion that it is a resource to spend across the life course", Smith et al. assert. "In line with other studies, just two in five Boh [banking on housing] participants expect to leave their housing wealth for inheritance; most plan to spend some (36\%) or all $(20 \%)$ of it before they die, either on high days and holidays, or to meet a more sobering array of welfare needs" (Smith et al., 2009, p.89). Yet, if there are "just two in five" people expecting to leave their housing wealth for inheritance, there are two in five plus $36 \%$ of people - making $76 \%-$ expecting to leave some housing wealth for inheritance. Housing wealth may no longer be primarily a legacy for future generations, but still, most people express the wish to leave something.

\section{Conclusion: The dispute surrounding bequest motives and its outlines}

What can be concluded from these empirical data about the motive to bequest? As shown by our enquiry on inheritance, younger generations do maintain that their parents' good life can be the best memory and gift to be passed on (Gotman, 1988). The offspring sincerely urge their parents to live their later life to the full as well as to free themselves from obligations at least for now. As they advocate for reciprocal independence, they free themselves from having to bother for their ageing parents too. May it be inferred, though, that parents and adult children do conform to the life cycle hypothesis standards about "bequest motives" - a matter duly screened, whose results appear delusive? ${ }^{3}$ When, instead of questioning bequeathing motives, questions are

in Skinner's view, "the debate about motives is 'a non-debate", since saving for bequests and precautionary saving are not substitutes, but could well be complements, in accordance with a combination of motives which probably explain wealth accumulation in the $17^{\text {th }}$ century, in 2002, and in the future (Skinner, 1985). 
focused on the problem of receiving an inheritance, it appears that the core motive to bequeath is to bequeath again - if not what has been received but the very fact of being a receiver (Gotman, 2006). Because the design to bequeath becomes real and considered only after one becomes oneself an heir, and bequeathing is anchored in the experience of inheritance, asking in abstract terms about bequest motives may not be relevant. Aside from that, questioning the intention to bequeath today does not fit with a society where transmission relationships are no longer constrained but, like marriage, freely agreed. Inheritance does not make social status anymore. Likewise, there is no straight obligation to support ascendants. Each generation enjoys its autonomy with its own incomes and savings, making a declarative intention to bequeath all the more unlikely. Passing on comes out more as a possibility than an intention, or eventually a wish, not openly expressed, for it is adverse to individual autonomy. Reciprocally, inheritance is no longer an "expectation" and not a subject to be openly touched upon by adult children. That is why potential receivers dare even less than their counterparts (potential bequeathers) to declare themselves as such. To not speak about inheritance has become the normative expression of present succession relationships. Today, this last reason may perfectly account for silent transmission attitudes, not speaking out of a repulsion to think about death. Bequest should not be spoken of and waiting for inheritance even less, yet, intergenerational transfers do increase at the same time as household wealth does. They may increase even more due to the growing feeling that children now will not manage as well as their parents did in their time. The feeling of accrued precariousness, the fear that children are to face more economic difficulties, and that their family life will be more vulnerable may explain why the same young respondents who declared not to be waiting for any inheritance maintain that they do wish to leave a bequest. Besides, it appears from French notary records that divorced parents are more quick and eager to make a will than their non divorced counterparts. Bequest practices among divorced people are many, depending mainly on the time of the divorce. If it is an early divorce, first-marriage children are poorly provided for. If it is on the contrary a later divorce, they will be much more generously provided for. Like family itself, inheritance patterns move along with changing mores and manners. That is the way they resist most of them.

It may also be noted that if reverse mortgages are to be especially relevant for low income homeowners, inequalities in the propensity to bequeath will increase too. At present, bequeathing inequality follows transmitters' incomes. People with the highest incomes pass on the highest bequests in value; 
reciprocally, people with the lowest incomes pass on the lowest bequests (Rowlingston and McKay, 2005; Laferrère, 1990). Bequest inequalities also go the other way, as they are more surprisingly related to receivers' incomes as well. The less the receiver's income, the less her inheritance. There is no compensation between social and cultural inheritance on the one hand, and material inheritance on the other. Both work hand in hand. Reducing the propensity to bequeath among those with lower incomes will not only increase inequalities between older generations' capacity to bequeath, but also between members of the inheriting generation.

While depleting bequests and inheritances, reverse mortgages enforce the normative economic statement of the house as a consumption good. States' high levels of debt as well as growth mottos make low and middle-class decumulation processes seen as an inescapable trend. The life cycle hypothesis of which reverse mortgages are a straight application implies that elderly security savings should be drawn down from home ownership and bequest practices given up. The question here is whether this model fits with people's actual uses and wishes. To that, we may answer that reverse mortgages buyers do not agree with the life cycle hypothesis requisites. For attitudes towards bequest did not fall into abeyance. Indeed, one should consider a society where the home, no longer the place of social and family aggregation, reduced to its market value and dematerialized in the same way as money, would be vowed to be an insurance product. One should finally consider a society which would have done away with the very idea of transmission. In that respect, the so called "reverse" mortgages would indeed accomplish a profound reversion of the anthropological sense of home.

\section{References}

A decent quality of life. Inquiry into the cost of living pressures on older Australians. Canberra: Senate, Standing Committee on Community Affairs, 2008.

ASSIER-ANDRIEU, Louis; GOTMAN, Anne. Réversion du principe du logement humain. Chronique du prêt hypothécaire inversé. Paris: Plan urbanisme construction architecture, Ministère de l'écologie, de l'énergie, du développement durable et de l'aménagement du territoire/Centre de recherche sur les liens sociaux, Université Paris Descartes, 2009.

Canadian Home Income Plan (CHIP). www.chip.ca

DAVEY, Judith A.; WILTON, Virginia. Home equity conversion schemes in NewZealand: consumer perspectives. Victoria: University of Wellington, New Zealand Institute for Research on Aging, 2006.

DAVEY, Judith A. Equity release: an option for older home-owners. York: Center for Housing Policy, 1997. 
DOLAN, Alex; McLEAN, Peter; ROLAND, David. Home equity, retirement incomes and family relationships. Melbourne: Department of Family and Community Services, 2005.

GIBLER, Karen M.; RABIANSKI, Joseph. Elderly interest in home equity conversion. Housing Policy Debate, v. 4, n. 4, p. 565-588, 2006.

GOTMAN, Anne. Hériter. Paris: Presses Universitaires de France, 1988.

GOTMAN, Anne. L'Héritage. Paris: Presses Universitaires de France, 2006.

Housing Finance in the Euro Area, 2009. European Central Bank, Task Force of the Monetary Policy Committee of the European System of Central Banks, Occasional Paper Series n 101 .

HOWE, Anna; HEALY, Judith. Generational justice in aged care policy in Australia and in the United Kingdom. Australian Journal on Ageing, v. 24, Suppl, p. S12-S18, 2005.

LAFERRERE, Anne. Successions et héritiers. Paris: INSEE Cadrage n. 4, 1990.

LE GOFF, Philippe. The reverse mortgage: a solution to retirement funding? Otawa: Parliament Research Branch, Economics Division, 2003.

LEVITON, Roberta. Reverse mortgage decision-making. Journal of Aging \& Social Policy, v. 13, n. 4, p. 1-16, 2001.

MAXWELL, Dominic; SODHA, Sonia. Housing wealth. First timers to old timers. London: Institute for Public Policy Research, 2006.

MERLIS, Mark. Home equity conversion mortgages and long-term care. Washington D.C.: Health Policy Institute, Georgetown University, 2005.

MITCHELL, Olivia S.; PIGGOTT, John. Unlocking housing equity in Japan. Wharton School of Pennsylvania: Pension Research Council Working paper n. 3, 2003.

ONG Rachel. Unlocking housing equity through reverse mortgages: The case of elderly homeowners in Australia. European Journal of Housing Policy, v. 8, n. 1, p. 61-79, 2008.

REDFOOT, Donald L.; SCHOLEN, Ken; BROWN, S. Kathi. Reverse mortgage: niche product or mainstream solution? Washington D.C.: AARP, 2007.

Report on Reverse Mortgages. British Columbia Law Institute: Canadian Center for Elderly Law Studies, CCELS Report 2, DCLI Report 41, 2006.

Reverse Mortgages. Law Reform Commission of Saskatchewan Consultation Paper, 2006.

RODDA, David T.; HERBERT, Christopher; LAM, Hin-Kin. No place like home: evaluation report of FHA's home equity conversion mortgage insurance demonstration. Washington D.C.: U.S. Department of Housing and Urban Development, 2000.

ROWLINGSTON, Karen; McKAY, Stephen. Attitudes to inheritance in Britain. London: Joseph Rowntree Foundation, 2005.

SCHOLEN, Ken; BELLING, Bronwyn. Home equity conversion mortgage (HECM) Counseling. Washington D.C.: Neighborhood Reinvestment Training Institute, 2006. 
SKINNER, Jonathan. Variable lifespan and the intertemporal elasticity of consumption. Review of Economics and Statistics, p. 616-623, 1985.

SMITH, Susan J.; SEARLE, Beverley A.; COOK Nicole. Rethinking the risks of home ownership. Journal of Social Policy, v. 38, n. 1, p. 83-102, 2009.

SMITH, Susan J. Banking on housing? Speculating on the role and relevance of housing wealth in Britain. Inquiry into Home Ownership 2010 and Beyond. London: Joseph Rowntree Foundation, 2005.

STUCKI, Barbara R. Use Your Home to Stay at Home. Expanding the Use of Reverse Mortgages for Long-Term Care: A Blueprint for Action. Washington D.C.: The National Council on The Aging, 2005.

STUCKI, Barbara R. Using reverse mortgage to Manage Financial Risk of long-term care. Las Vegas: Retirement Assets Symposium, Society of Actuaries, 2004.

TERRY, Rachel; GIBSON, Richard. Obstacles to equity release. London: Joseph Rowntree Foundation, 2006.

VENTI, Steven F.; WISE, David A. Aging and housing equity: another look. Cambridge Mass.: National Bureau of Economic Research, 2001. Working Paper 8608.

VENTI, Steven F.; WISE, David A. Aging and the income value of housing wealth. Journal of Public Economics, v. 44, p. 371-397, 1991.

What Are the Health Challenges Facing Australia? Will Changes to State and Commonwealth Responsibilities Meet the Challenges? Canberra: National Foundation for Australian Women, Record of proceedings, 2005. 